\title{
Model Based Dispatch Optimisation for Residential Districts - Analysing the Integration of Electricity Storage Systems and their Environmental Impact
}

\author{
Steffen Lewerenz \\ Pforzheim University
}

In the European Union, residential districts consume a significant share of the total electricity, which is still mainly generated by conventional power plants. Consequently, utilising renewable energy carriers combined with electricity storage systems are necessary to mitigate climate change. To assess the electricity generation and the storage operation a techno-economic bottom-up model is applied and combined with a Life Cycle Assessment to evaluate the environmental impacts of the applied electricity storage system. Under the taken assumptions electricity storage systems have the potential to increase the degree of self-supply and autarky of the energy system as far as their prices decrease.

Keywords: Energy System Modelling, Electricity Storage Systems, Life Cycle Assessment

\section{INTRODUCTION}

Households account for $29 \%$ of the entire electricity consumption in the European Union (eurostat, 2017). As the electricity generation in the European Union is still covered to $74 \%$ by conventional power plants, households contribute significantly to the emission of greenhouse gases (eurostat). Consequently, designing a sustainable energy system for residential districts is important to mitigate climate change. Substituting fossil fuels by renewable energies includes the utilisation of energy carriers such as solar and wind energy. To address their fluctuation and the temporal shift between power generation and consumption, electricity storage systems (ESS) are needed to secure a safe energy supply (Samsatli \& Samsatli, 2018). There is a variety of storage technologies available, which cause environmental impacts by their production and utilisation, for instance resource depletion and climate change (Baumann, Peters, Weil, \& Grunwald, 2017; McManus, 2012; Weber, Peters, Baumann, \& Weil, 2018). Subsequently, finding an optimal economic and ecologic solution for residential districts is essential to balance resource use, climate change and costs.

Real-world systems are usually represented by models (Wiese, Hilpert, Kaldemeyer, \& Pleßmann, 2018). There is a variety of models, model generators or frameworks available to create and calculate energy system models (Hall \& Buckley, 2016). Previous studies have analysed national (Rauner \& Budzinski, 2017), international energy systems (Volkart, Mutel, \& Panos, 2018) or small networks (household networks) in particular. Dispatch optimisation of energy system models that represent an accumulation of household networks are currently underrepresented. In the area of small networks, ESS integration is considered, for instance in Zhang et al. (2012) and Naumann et al. (2015), whereas it is neglected in more extensive energy systems, e.g. in Barteczko-Hibbert et al. (2014). Moreover, if a storage facility is present in a system, often only one storage technology is investigated, e.g. in Huneke et 
al. (2012) or Rauner and Budzinski (2017). Stadler et al. (2012) investigate the environmental impacts of a house's power supply and take into account the charging of battery electric vehicles (BEV). However, electromobility is hardly integrated into other studies. In the field of energy system modelling, Life Cycle Assessment (LCA) is rarely conducted concerning the utilised ESS. This raises the question about the influence of different storage technologies on the dispatch and the environmental effects of an energy system. In order to determine the environmental impacts, LCAs have already been prepared for various stationary battery storage systems. However, the number is still small (Peters \& Weil, 2018). In addition, efficiency, power dependence and life cycles are rarely considered (Spanos, Turney, \& Fthenakis, 2015). To the author's knowledge, LCA of concrete applications of various battery storage devices in neighbourhood power networks have not yet been investigated.

This paper searches for an optimal dispatch for a valve-regulated-lead-acid (VRLA), lithium-ion-ironphosphate (LFP) and vanadium-redox-flow (VRF) battery by considering their efficiencies and life expectancies in on-grid and off-grid situations to deduce an adequate battery capacity. In order to address a future shift to BEVs, different shares are considered. Finally, a LCA, based on recent literature is conducted to evaluate the environmental impact of the utilised storage systems. As a result, an open source optimisation model for the electricity supply of a residential district is created to address climate change by the utilisation of renewable energies and ESS under the consideration of security supply aspects as well as economic and ecologic factors.

\section{Background}

Recent literature applies energy system modelling mostly for component sizing, component location, comparative analysis and operational management (Bordin, 2015). For instance, in Zhang et al. (2012), Puri (2013) and Huneke et al. (2012) the component design serves, among other things, to determine the required power, the number and the capacity of the applied generation as well as storage technologies. The comparative analysis is used to compare different optimisation methods, such as the deterministic method compared to the generic method e.g. in Upadhyay and Sharma (2013). Optimisation of operational management is often aimed at minimising operating costs. In grid-connected models, it is possible to feed surplus electricity into the grid and thus sell it on the electricity exchange (Bordin et al., 2017). For example, Chen et al. (2010) are investigating a self-sufficient power grid with the aim of storing surplus electricity generated by renewable energies for a later utilisation. Mustonen and Nanthavong (2006) analyse the electricity grid of a village over a 24-hour operating period and go into more detail on the non-linearity of the cost development of the electricity producers. Kriett and Salani (2012) additionally integrate the influence of electromobility into the household grid they are investigating. Research into environmental influences are more frequently linked to component design for instance in Kazemi and Rabbani (2013) and Chedid and Rahman (1997). In the field of operational management, Stadler et al. (2012) investigate the influence of electromobility on the power grid of a house, whereby costs or carbon dioxide emissions can be optimised (Stadler et al., 2012). In addition to examining environmental impacts in the household sector, other authors examine global or national energy systems and integrate environmental impacts into their optimisation e.g. in Rauner and Budzinski (2017), Barteczko-Hibbert et al. (2014) and Volkart et al. (2018). LCA is often used to determine the potential environmental impacts of products or processes (Deutsches Institut für Normung e.V., 2019). Peters et al. (2017) identify 79 LCAs about lithium-ion-batteries and 34 LCAs about electromobility. The LCAs on electromobility examine the use of BEV in comparison to conventional vehicles, whereby the batteries are considered as part of the BEV (Spanos et al., 2015). Of the 79 studies, only a few investigate the production phase of stationary battery storage systems (Peters \& Weil, 2018). An example for the investigation of stationary battery storage is provided by McManus (2012), which investigates the production of $1 \mathrm{~kg}$ or $1 \mathrm{MJ}$ capacity of different battery types considering the energy densities of the technologies. In addition to McManus (2012), Rydh and Sandén (2005) determine the cumulative energy demand for a battery storage system with $50 \mathrm{~kW}$ power and $450 \mathrm{kWh}$ capacity with an electricity supply of $150 \mathrm{kWh}$ through photovoltaic over the production and utilisation phase. They consider different battery technologies taking into account different discharge depths, efficiencies and energy densities. In 
addition to this work on different battery technologies, Weber et al. (2018) analyse the provision of 1 MWh of electricity over 20 years by a vanadium-redox-flow battery, taking into account the production, utilisation and disposal phase. A more recent comparison of stationary ESS is provided by Baumann et al. (2017), which determine the carbon dioxide footprint and the life cycle costs for a wide variety of battery technologies on the basis of their energy densities, efficiencies, cycle life and costs.

\section{METHODS}

A techno-economic bottom-up model for a residential district based on hourly data is created and combined with an LCA for the utilised ESS. The energy system model is created by using the open energy modelling framework (oemof) (Hilpert et al., 2018), which is an open source framework developed at the University of Applied Sciences in Flensburg. Oemof optimises the modelled energy system with the goal of minimising the sum of variable costs $\left(\mathrm{c}^{\mathrm{var}}\right)$ for the total period of time $(\mathrm{T})$ according to equation (1) with $f_{(p, s), t}$ being the flow between its predecessor (p) and its successor (s) component in timestep (t) multiplied with the length of the timestep $\left(\tau_{t}\right)$ (Wingenbach, Hilpert, \& Kaldemeyer, 2017). A full description of the framework contains the documentary of oemof (oemofTeam, 2019). The complete mathematical approach is explained in Manfren (2012).

$\min : \sum_{t \in T} \sum_{(p, s) \in F} c_{(p, s), t}^{v a r} * f_{(p, s), t} * \tau_{t}$

The parametrisation of the model is realised by a literature research for specific technologic and economic data for power generation plants, ESS and load profiles representing households and BEVs. A simplified representation of the model is displayed in FIGURE 1. Scenarios are defined which consider different situations of grid operation. Off-grid as well as on-grid operation with different amounts of BEVs are investigated. Following, the dispatch optimisation of the scenarios for the time period of one year is carried out. Adding the ecological pillar to the model an LCA is conducted to evaluate the environmental burden of the utilised ESS.

FIGURE 1

SIMPLIFIED ENERGY SYSTEM MODEL

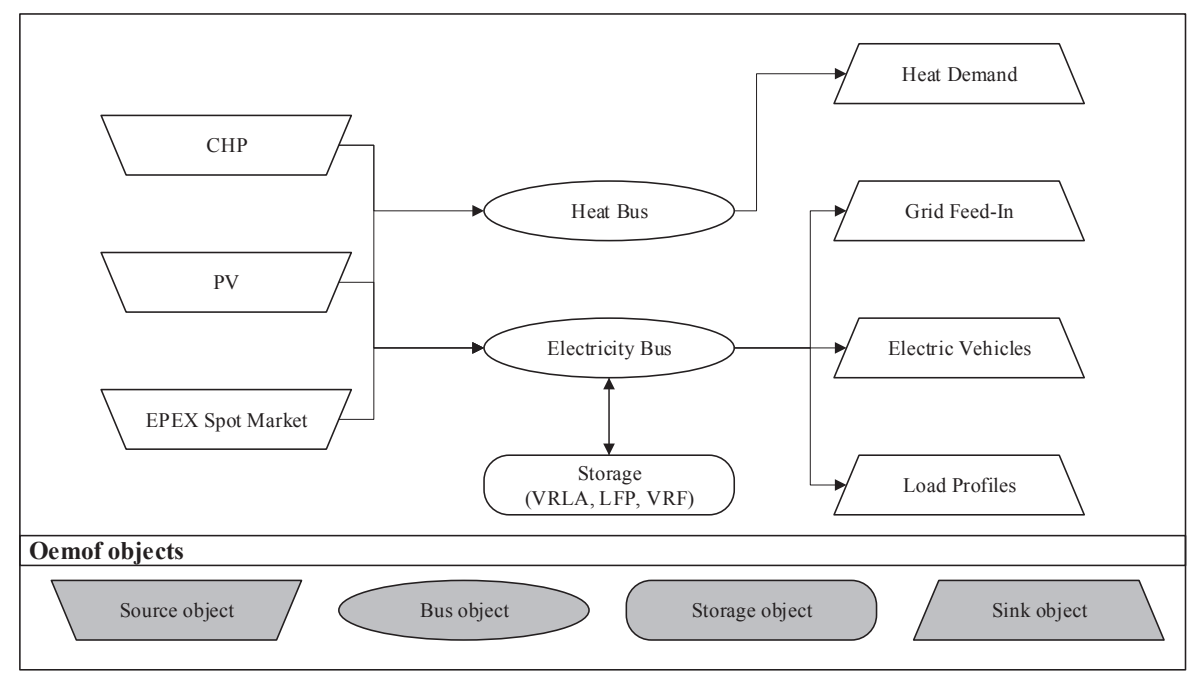

\section{Demand Modelling}

The applied load profiles were metered with a resolution of 15-minutes during 2008 to 2011 for 497 households (IZES gGmbH, 2012). Tjaden et al. (2015) select 74 load profiles from 2010 with typical 
seasonal and daily performance of households electricity consumption and are closing data gaps to create 1 -second sampled load profiles. The load profiles are again adapted to an hourly resolution and adjusted to the 2017 calendar year. The total demand accounts for $346,836 \mathrm{kWh}$ per year with a maximum power demand of $98 \mathrm{~kW}$.

To model the electricity demand of BEVs, load profiles published from Schäuble et al. (2017) and created from Heinz (2018) are utilised. Heinz (2018) creates different load scenarios for BEVs in his work. In the model the load profile type 3 is applied assuming that the BEV is only charged at home. The charge power accounts for $3.7 \mathrm{~kW}$ resulting in a total demand of $1,433 \mathrm{kWh}$ per year. The load profiles are converted to hourly values and adjusted to the 2017 calendar year. Different load profiles for weekdays and weekends are applied. The amount of BEVs is varying over the defined scenarios.

\section{Energy Generation Modelling}

The energy supply is provided by combined heat and power (CHP), photovoltaics (PV) and the electricity grid. The CHP is fired with natural gas and designed based on the electricity load curve of the households. It is assumed that all generated heat will be consumed and sold at break-even for instance to provide thermal energy to a heat grid. The CHP is designed to reach 6,000 full load hours per year. Consequently an electric power of $30 \mathrm{~kW}$ resulting in a total power of $101 \mathrm{~kW}$ is installed (ETZ-EnergieTechnik der Zukunft, 2018). The electricity generation from the CHP is not controlled by a load profile. It is only limited by the total maximum power and the variable costs. The variable costs of the CHP are containing costs for fuel, lubricating oil and maintenance, which are estimated based on ASUE e.V. (2011). To allocate the total variable costs to generated heat and electricity, the total efficiency method is applied (Hörner, 2013). This method is based on the thermal and electric efficiency of the CHP and a reference system thus securing a realistic allocation of the costs. Based on the above-mentioned assumption concerning the heat consumption the variable costs for heat are set to zero. The variable costs for the generated electricity account for $1.1307 €$ cent per $\mathrm{kWh}$.

To cover the remaining electricity demand PV is utilised. Assuming a generation of $180,000 \mathrm{kWh}$ covered by the CHP and a total demand of $346,836 \mathrm{kWh}$ a residual demand of 166,694 kWh exists. In Germany, the average PV system size accounted for $7 \mathrm{kWp}$ for newly installed systems in 2018 (Bundesnetzagentur, 2018). By generating a load profile of a $7 \mathrm{kWp}$ PV system located in Pforzheim, with a system efficiency of $15 \%$ (Konstantin, 2017) results in an electricity generation of $6,964 \mathrm{kWh}$ per year. The load profile is generated with an hourly resolution by utilising the PV GIS of the European Commission (European Commission, 2017), which exhibits a high accuracy (European Commission, Joint Research Centre, Renewable Energies Unit, 2006). This equals an installed capacity of $168 \mathrm{kWp}$. Applying a security factor of $10 \%$ results in $184 \mathrm{kWp}$ installed capacity, which is distributed over 26 households. Operational costs for PV systems are caused by maintenance and operation (Kaltschmitt, Streicher, \& Wiese, 2013). Although being fixed costs those are allocated over the generated electricity as the amount of kilowatt-hours generated is constrained. Thus, variable costs account for $5.528 €$ €ent per kWh.

As a reference system the model has the possibility to consume electricity from the electricity grid, which is represented by the European Power Exchange (EPEX) spot market prices of 2017. The hourly price profile is fed into the model. The electricity supply from the grid is only constrained by the hourly prices. Caused of errors raising when applying negative prices, all negative prices are set to zero.

\section{Electricity Storage System Modelling}

Three battery types are analysed based on available manufactures data. The SAGM 12V/205Ah (Trojan Battery Company) represents a VRLA, the TR 12.8V/92Ah (Trojan Battery Company) a LFP and the VoltStorage SMART ("Technisches Datenblatt") a VRF. The utilised batteries are represented as a storage object in oemof (Hilpert et al., 2018). According to oemof the storage object is defined by the nominal capacity, maximum input (charge rate) and output flows (discharge rate), capacity loss, initial capacity, inflow and outflow efficiency and the maximal depth of discharge (DOD $\left.{ }_{\max }\right)$. Subsequently, the calculation of the needed parameters is explained. 
Generally, the nominal capacity of batteries is measured by ampere hours (Ah). To work in kWh the capacity is multiplied with the nominal voltage of the battery, assuming an ideal battery (Argent-Katwala, Dingle, \& Harder, 2009). The installed capacity is estimated according to Waffenschmidt (2014), which conclude that per $\mathrm{kWp}$ installed power PV one $\mathrm{kWh}$ of storage capacity is economically viable $\left(\mathrm{Q}_{\text {inst,BatPV }}\right)$. The second analysed capacity $\left(\mathrm{Q}_{\text {inst,BatLP }}\right)$ is calculated based on an average daily electricity consumption of the analysed residential district. Because of the possibility to trade electricity three days in advance at the EPEX, the second analysed battery capacity is able to cover three days. Although the battery suffers from calendric and cycling degradation (Bordin, 2015; Naumann et al., 2015) the capacity is assumed to be constant.

The maximum discharge rate is calculated based on the installed capacity divided by the possible discharge time provided by the manufacturer. Thus, the capacity is secured to be available although higher discharge speeds might be possible. Due to the lack of data concerning charge rates the maximum charge rate is assumed to equal the maximum discharge rate. Only one datasheet (Trojan Battery Company) provides a charge rate, which is higher than the discharge rate. In contrast, in Yoshida et al. (2016) the charge rate is lower than the discharge rate for a lithium-ion-battery, thus the assumption is a compromise. The total efficiency (DC-DC) is taken from Baumann et al. (2017). Monthly storage losses are based on Sterner and Stadler (2017) and are converted into hourly efficiencies $\left(\eta_{\text {storage }}\right)$. By equating charge and discharge efficiency the discharge efficiency is calculated by equation (2) (Bordin et al., 2017; Peterson, Whitacre, \& Apt, 2010). Differences between $\eta_{\text {charge }}$ and $\eta_{\text {discharge }}$ can be assumed to be 5\% (Huneke et al., 2012) and result in a slight misallocation of storage losses. To include losses resulting from inverting $\mathrm{AC}$ to $\mathrm{DC}$ the DC-DC efficiency is multiplied with the square of the inverter efficiency of $95 \%$ (Konstantin, 2017) resulting in the total AC-AC efficiency.

$\eta_{\text {charge }}=\eta_{\text {discharge }}=\sqrt{\frac{\eta_{\text {total }, D C-D C}}{\eta_{\text {storage }}}}$

The minimal state of charge $\left(\mathrm{SOC}_{\min }\right)$ is based on values from Baumann et al. (2017). The starting capacity $\left(\mathrm{SOC}_{\text {start }}\right)$ is set to $50 \%$ of the total installed capacity.

The variable costs for the utilised ESS are calculated by using the ampere hours throughput (Ah-model) model, thus considering their cycle life (Bindner, 2005). The Ah-model is applicable as it allows an estimation of battery cycle life without needing exact information of the analysed battery, although it neglects the exact process of (dis)charging (Beer \& Rix, 2016). It utilises the lifetime curve of the battery, which is provided by datasheets of the manufactures and displays the amount of cycles to failure depending on different DOD until end of life of the battery. Thus, it is easy to apply and is frequently used (Bordin et al., 2017; Peters et al., 2017; Spanos et al., 2015). By applying the installed capacity ( $\left.\mathrm{Q}_{\text {inst,bat }}\right)$ in Wh the total lifetime throughput (LT) is calculated as described in equation (3) (Bordin et al., 2017). Averaging different DOD $\left(d_{n}\right)$ and their corresponding cycles to failure $\left(f_{n}\right)$ results in an average $\mathrm{LT}$ value. The factor $\mathrm{n}$ depends on the considered $\mathrm{DOD}_{\max }$.

$L T_{\text {total }}=\frac{\sum_{l=1}^{n} L T_{n}}{n}=\frac{1}{n} * \sum_{l=1}^{n}\left(Q_{\text {inst }, \text { bat }} * d_{n} * f_{n}\right)$

By defining the calendric lifetime to be 10 years, which is the minimum lifetime for VRLA (Baumann et al., 2017) a LT per year ( $\mathrm{LT}_{\text {year }}$ ) can be derived. Based on the $\mathrm{LT}_{\text {year }}$ variable costs are calculated based on literature data from (Baumann et al., 2017). They publish operation and maintenance costs for batteries, not considering the electricity demand for periphery or battery management system (BMS). Those operational costs are already included in the AC-AC efficiency of the ESS (Sterner \& Stadler, 2017). In addition battery degradation costs are considered based on investment costs from Baumann (2017). Generally, the end of life of a battery is reached when the available battery capacity decreases to $80 \%$ of its initial capacity (Krieger, Cannarella, \& Arnold, 2013; Ramoni \& Zhang, 2013). Consequently, up to $80 \%$ of initial capacity is remaining (Bobba et al., 2018; Ramoni \& Zhang, 2013; 
Reid \& Julve, 2016). Although other research suggest a non-linear degradation of the battery after reaching the 80\% (Jongerden \& Haverkort, 2017; Keil, Schuster, Lüders, \& Hesse, 2015) it is assumed that only a replacement investment of $20 \%$ (i) of the initial investment must be undergone as the stationary application of batteries is a less stressful application (Reid \& Julve, 2016). This is an optimistic assumption taken. As a result of the optimisation an application of 100\% would lead to almost no ESS operation. Finally, the battery degradation costs $\left(\mathrm{BDC}_{\mathrm{kWh}}\right)$ are calculated according to equation (4) (Bordin et al., 2017). Adding the variable costs for operation and maintenance results in the total costs per $\mathrm{kWh}_{\mathrm{LT}}$, which arise for every charged $\mathrm{kWh}$ in the ESS.

$B D C_{k W h}=i * \frac{C_{r e p} * Q_{\text {inst }, \text { bat }}}{L T_{\text {total }}}$

A summary of all parameters set in the model is depicted in TABLE 1.

\section{Scenario Analysis}

Scenario I assumes a grid connected energy system with no BEV in the system. The scenario shall indicate how economically viable an ESS can be utilised in collaboration with PV and CHP compared to the consumption of electricity from the grid. The installed capacities of $\mathrm{Q}_{\text {inst,BatPV }}, \mathrm{Q}_{\text {inst,BatLP }}$ are analysed, thus the scenario is divided into IPV and ILP. Furthermore, self-supply degree and autarky degree are calculated. All results are compared to a base scenario without an integrated ESS.

Scenario II assumes a grid connected energy system with 74 electric vehicles in the system. The installed capacities of $\mathrm{Q}_{\text {inst,BatPV }}, \mathrm{Q}_{\text {inst,BatLP }}$ are again analysed, thus the scenario is divided into IIPV and IILP. It will display the impact of an increasing use of electromobility on the operation of residential districts.

Scenario III assumes an off-grid energy system and is analysed without any electric vehicle connected. The installed capacities of $\mathrm{Q}_{\text {inst,BatPv }}, \mathrm{Q}_{\text {inst,BatLP }}$ are analysed, thus the scenario is divided into IIIPV and IIILP. As the energy demand cannot be fully provided by the modelled electricity generation an extra electricity provider is installed. This emergency generation is integrated instead of the EPEX spot market and highly priced. Thus, it is only activated when electricity is missing. Consequently, this scenario will show whether a battery storage system combined with PV and CHP can supply the system autarky. 
TABLE 1

SUMMARY OF PARAMETERS

\begin{tabular}{|c|c|c|c|}
\hline Energy generation & CHP & PV & Grid \\
\hline $\mathbf{P}_{\text {installed,el }}[\mathbf{k W}]$ & 30 & 184 & $1,000,000$ \\
\hline $\mathrm{C}_{\mathrm{var}, \mathrm{el}}[\boldsymbol{€ c e n t} / \mathbf{k W h}]$ & 1.131 & 5.528 & EPEX Spot 2017 \\
\hline ESS & VRF & LFP & VRLA \\
\hline $\mathbf{Q}_{\text {inst,BatPV }}\left[\mathbf{k} \mathbf{W h} \mathbf{h}_{\text {inst }}\right]$ & 182 & 182 & 182 \\
\hline $\mathbf{Q}_{\text {inst,BatLP }}\left[\mathbf{k W h} \mathbf{h}_{\text {inst }}\right]$ & 2,850 & 2,850 & 2,850 \\
\hline $\mathbf{L T}_{\text {spez }}\left[\mathbf{k W h} \mathbf{h}_{\mathbf{L T}} / \mathbf{k W h} \mathbf{h}_{\text {inst }}\right]$ & 873 & 3,854 & 10,000 \\
\hline $\mathbf{P}_{\text {max,chargePV }}=\mathbf{P}_{\text {max,dischargePV }}[\mathrm{kWh}]$ & 25 & 36 & 18 \\
\hline $\mathbf{P}_{\text {max, chargeLP }}=\mathbf{P}_{\text {max, dischargeLP }}[\mathbf{k W h}]$ & 390 & 570 & 285 \\
\hline$\eta_{\text {storage }}[\%]$ & 98.75 & 99.90 & 99.29 \\
\hline$\eta_{\text {charge }}=\eta_{\text {discharge }}[\%]$ & 82.79 & 93.08 & 83.39 \\
\hline$\eta_{\text {total,AC-AC }}[\%]$ & 69.53 & 86.73 & 68.54 \\
\hline DOD $_{\max }[\%]$ & 80 & 77 & 56 \\
\hline $\mathrm{SOC}_{\text {start }}[\%]$ & 50 & 50 & 50 \\
\hline 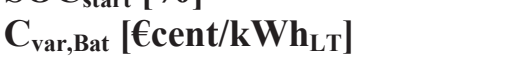 & 0.547 & 1.297 & 1.936 \\
\hline $\mathrm{BDC}_{\mathrm{kWh}}[€ \operatorname{cent} / \mathbf{k W h} \mathrm{LT}]$ & 0.916 & 1.604 & 5.269 \\
\hline $\mathrm{C}_{\mathrm{var}, \text { Bat,total }}[€ \operatorname{cent} \mathrm{t} / \mathbf{k W h} \mathrm{LT}]$ & 1.463 & 2.901 & 7.205 \\
\hline
\end{tabular}

\section{Life Cycle Assessment}

LCA is a preferred approach to quantifying potential environmental impacts and is frequently applied (Majeau-Bettez, Hawkins, \& Strømman, 2011; Peters et al., 2017; Spanos et al., 2015). Due to its life cycle approach all stages of life concerning a product or process from material mining over procurement, production, use and end-of-life is considered. All material and energy inputs assigned to processes or products must be included (Deutsches Institut für Normung e.V., 2019). LCA is based on the ISO 14044, which is a framework how to conduct an LCA (Deutsches Institut für Normung e.V., 2018; Zackrisson, Avellán, \& Orlenius, 2010).

The goal of the assessment is to provide an analysis of the applied ESS. It is supposed to assist on the decision which ESS to utilise considering the potential environmental impact. FIGURE 2 depicts the analysed product system and visualises the system boundaries. Production including transport and use phase are analysed. The end-of-life stage is disregarded as the analysed time period is one year. Furthermore, this approach is used in Zackrisson et al. (2010). Recycling processes are already available for VRLA but not yet established for VRF and LFP (Baumann et al., 2017).

FIGURE 2

ANALYSED PRODUCT SYSTEM

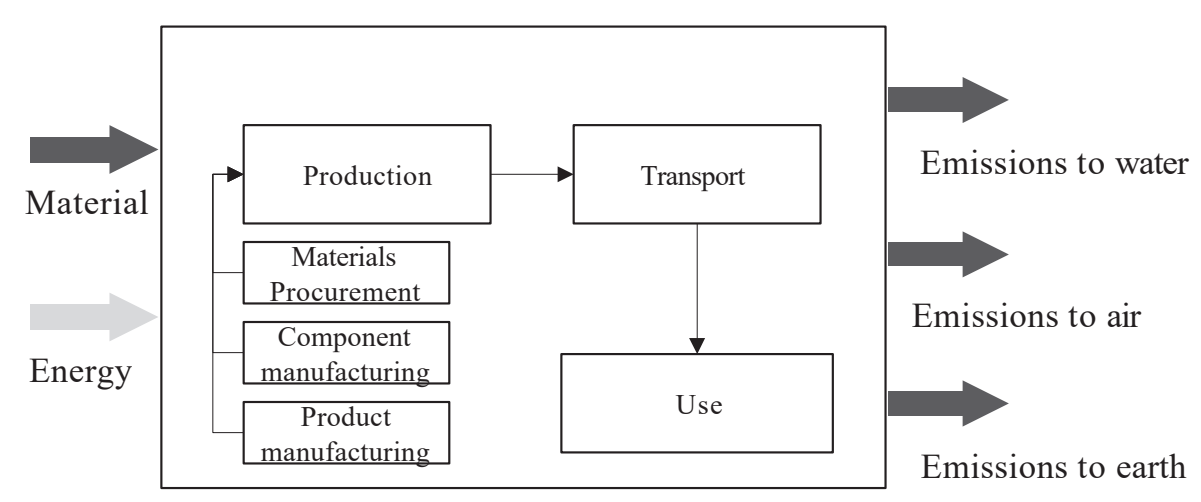

62 Journal of Strategic Innovation and Sustainability Vol. 14(6) 2019 
Often the functional unit is based on installed battery capacity e.g. in McManus (2012). That approach is impractical as ESS properties, especially lifetime and efficiency are varying (Peters \& Weil, 2018; Spanos et al., 2015). By applying the approach of the lifetime throughput, which was already introduced for the variable costs' calculation for the ESS, the lifetime of the battery can be considered (Spanos et al., 2015). From manufactures data the specific lifetime throughput $\left(\mathrm{LT}_{\mathrm{spez}}\right)$ is derived following the equation (5) by averaging different DOD $\left(\mathrm{d}_{\mathrm{n}}\right)$ and their corresponding cycles to failure $\left(\mathrm{f}_{\mathrm{n}}\right)$. The factor $\mathrm{n}$ depends on the considered $\mathrm{DOD}_{\max }(\operatorname{See}$ TABLE 1$)$.

$L T_{\text {spez }}=\frac{\sum_{l=1}^{n} d_{n} * f_{n}}{n}$

Additionally, the AC-AC efficiency (See TABLE 1) is considered to calculate the electricity losses $\left(\mathrm{W}_{\text {loss }}\right)$ due to the storing process. $\mathrm{LT}_{\text {spez }}$ is derived from equation (5) where $\eta_{\text {total,AC-AC }}$ represents the ACAC efficiency of the ESS (See equation 6) (Spanos et al., 2015).

$W_{\text {loss }}=L T_{\text {spez }} *\left(1-\frac{1}{\eta_{\text {total }, A C-A C}}\right)$

Consequently, the functional unit is $1 \mathrm{MWh}$ discharged from the utilised ESS, without considering discharge due to losses.

The International Reference Life Cycle Data System (ILCD) (2011) midpoint impact assessment factors are applied as they contain the most advanced assessment factors according to Hauschild et al. (2013). There are 18 different impact categories defined in the ILCD. This study focuses on climate change, resources - mineral, fossils and renewables and ecosystem quality - freshwater ecotoxicity. This selection is based on Peters et al. (2017).

\section{Life Cycle Inventory}

The life cycle inventory for the ESS is based on a literature research and the ecoinvent 3.3 database (Wernet et al., 2016). The material procurement is primarily based on data from ecoinvent, whereas component and product manufacturing, transport and use phase are based on literature research thus being the foreground system. Procurement represents the background system. In the following the different inventories and methodology for the modelling of the LCA are described.

The foreground system of the VRLA is modelled according to Spanos et al. (2015) by utilising their published inventory. The battery management system (BMS) is modelled according to Ellingsen et al. (2014), as they provide the most detailed inventory for BMS (Peters \& Weil, 2018). It substitutes the balancing and control electronics applied by Spanos et al. (2015). The share of the BMS of the total weight is not adapted. As Spanos et al. (2015) analyse a battery with an energy density of 34 $\mathrm{Wh} / \mathrm{kg}$ the inventory is assumed to fit for the SAGM $12 \mathrm{~V} / 205 \mathrm{Ah}$, which exhibits an energy density of $35.39 \mathrm{Wh} / \mathrm{kg}$.

The inventory for the production of LFP batteries is based on the work of Peters and Weil (2018), which created unified inventories for lithium-ion-batteries. Zackrisson et al. (2010) describe the manufacturing process for $1 \mathrm{~kg}$ of LFP with an anode made of carbon, which is representing the utilised LFP TR 12.8V/92Ah. For the modelling default providers for BMS (Ellingsen et al., 2014), pack housing (Bauer, 2010), cell package (Ellingsen et al., 2014), electrolyte (Notter et al., 2010), cathode (Bauer, 2010) and anode binder (Peters, Buchholz, Passerini, \& Weil, 2016) according to Peters and Weil (2018) are set. The full inventory can be obtained from Peters and Weil (2018). As Zackrisson et al. (2010) analyse a battery with an energy density of $93 \mathrm{Wh} / \mathrm{kg}$ the inventory is assumed to fit for the TR $12.8 \mathrm{~V} / 92 \mathrm{Ah}$, which exhibits an energy density of $95.74 \mathrm{Wh} / \mathrm{kg}$.

The inventory for the production of $1 \mathrm{~kg}$ of VRF battery is based on Weber et al. (2018). The energy density is taken from Weber et al. (2018) as the datasheet does not provide any data. 
Preferably market processes from the ecoinvent database 3.3 are utilised to model the background system as those represent a consumption mix dependent on a region or product (Wernet et al., 2016). The production is assumed to take place in Europe, thus processes delivering energy are modelled when possible with European energy mixes. For the procurement of materials mostly global processes are applied, which use a global supply chain (Wernet et al., 2016).

To assess the transport from the production plant to the final user an average intra Europe transport distance of $600 \mathrm{~km}$ is assumed (eurostat). Furthermore, it is assumed that the inverter is transported with the battery as one system. The inventory of the inverter is scaled to the needed maximum power for each ESS thus the inverter size is varying for each applied battery system. As a result of the process an amount of kilowatt-hours installed capacity is calculated based on the energy densities of each ESS.

The use phase is basically just converting the delivered installed capacity into a $\mathrm{LT}_{\text {total }}$ by applying the $\mathrm{LT}_{\text {spez }}$ for each ESS. Considering the efficiency, a part of the $\mathrm{LT}_{\text {total }}$ is converted to losses, while the rest is usable electricity discharged from the battery. The considered electricity mixes to cover the battery losses is covered by the "market group for electricity, low voltage electricity, low voltage for Europe without Switzerland" from the ecoinvent database 3.3. assuming a usage in Europe.

\section{RESULTS}

\section{Dispatch Optimisation - Scenario I}

The optimisation of scenario IPV shows that only the LFP and the VRF battery system are able to decrease the total electricity demand of the modelled system compared to the base scenario. The VRLA is only charged to cover its losses due to the constrained minimum state of charge, thus it is increasing the energy demand of the system by 1,498 $\mathrm{kWh}$. The energy system with a VRLA applied, consumes the most energy from the electricity grid and utilises the lowest amount of PV and CHP generated electricity. Consequently, it exhibits the lowest degree in self-supply and autarky. The energy system using the LFP battery system consumes the lowest amount of electricity and decreases the consumption by 17,968 $\mathrm{kWh}$. Electricity supplied by the grid accounts for $62,417 \mathrm{kWh}$ and is the lowest value achieved in scenario I. A high utilised share of PV and CHP increases the degree of self-supply by $10 \%$ and autarky by $6 \%$ compared to the base scenario. The VRF system reduces the overall electricity generation by $9,534 \mathrm{kWh}$ and utilises the highest share of CHP and PV, which is mainly due to its comparatively high inefficiencies during charge, discharge and storage. A summary of the results is displayed in FIGURE 3. The ESS performances are displayed in FIGURE 4. PV electricity is mostly stored in the ESS followed by CHP and the grid. The VRLA exhibits the lowest amount of discharged electricity due to its expensiveness. The highest electricity losses are achieved by applying the VRF battery system, which suffers from the lowest total efficiency. The highest impact can be allocated to the losses during storing the electricity especially for higher installed capacities. The highest discharge - charge efficiency reaches the LFP system in scenario IPV with $84 \%$.

When analysing the yearly demand curve of the base scenario it exhibits the typical patterns with a higher electricity demand during winter periods and lower during summer periods. The entire year, electricity is supplied by the electricity grid, but showing a small amount during the summer period. The average CHP electricity generation accounts for $18.23 \mathrm{~kW}$ and is increased to $18.8 \mathrm{~kW}$ by utilising the LFP. The CHP only charges electricity into the battery during winter periods, when electricity generation from PV is decreasing and EPEX prices are high. The electricity supplied by the grid is reduced and reaches its smallest value during summer periods. During winter periods grid electricity supply increases due to lower PV generation. Noticeable are peaks of grid electricity supply due to falling electricity prices up to $0 €$ cent per $\mathrm{kWh}$. The average grid electricity charge power accounts for $0.2 \mathrm{~kW}$ over the year. The PV electricity feed-in the grid can be delayed by eight days compared to the base scenario. High electricity feed-in from PV is available from the $52^{\text {nd }}$ day until the $305^{\text {th }}$ day. The average PV charge power into the ESS accounts for $2.6 \mathrm{~kW}$ over the year.

Utilising the VRF system, almost the same yearly curve occurs, showing a slightly higher charge of PV electricity into the battery over the year most likely due to the higher losses of the VRF battery. The 
average electricity power of CHP increases to $19.4 \mathrm{~kW}$. PV and grid electricity are charged into the battery with an average power of $3.4 \mathrm{~kW}$ and $0.4 \mathrm{~kW}$ respectively. Concerning the VRLA the dispatch optimisation results show almost the base scenario due its high battery degradation costs.

Scenario ILP shows a tremendous increase in grid electricity consumption of 23,208 $\mathrm{kWh}$ for the VRLA and 31,883 kWh for the VRF system. Only the LFP system slightly reduces the grid electricity consumption by $92 \mathrm{kWh}$. The VRLA and VRF systems store higher amounts of electricity generated by PV and CHP to cover their efficiency losses. This results in higher self-supply rates, as battery losses are considered as demand. Only the LFP system is able to deliver a significantly higher amount of electricity than in scenario IPV, which leads to a slight increase in the degree of autarky $(+2 \%)$ and self-supply $(+2 \%)$. The increase is also based on higher losses of the battery, which are covered by a higher electricity charge from PV. All results are summarized in TABLE 3.

The analysed yearly demand curve exhibits higher charge power into the ESS by the electricity grid, especially during price periods when prices falling to $0 €$ cent per $\mathrm{kWh}$.

FIGURE 3

\section{SCENARIO I - UTILISED ELECTRICITY GENERATION FOR DEMAND COVERING}

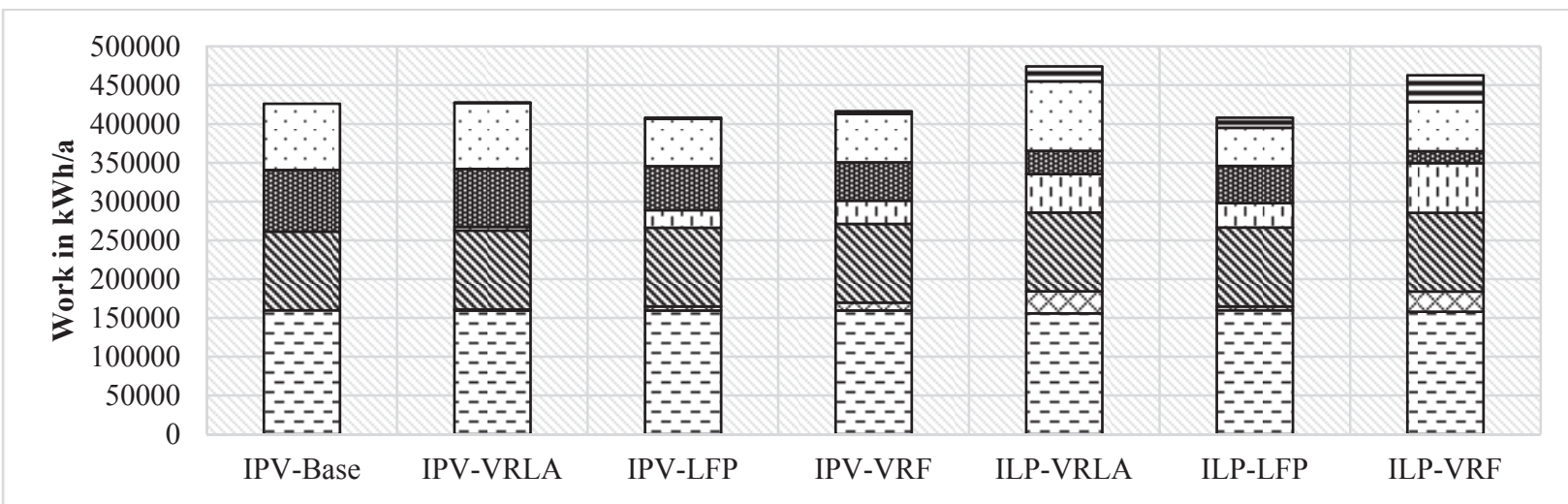

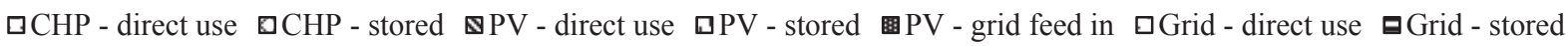

\section{FIGURE 4 \\ SCENARIO I - STORAGE CHARGE/DISCHARGE PERFORMANCE}

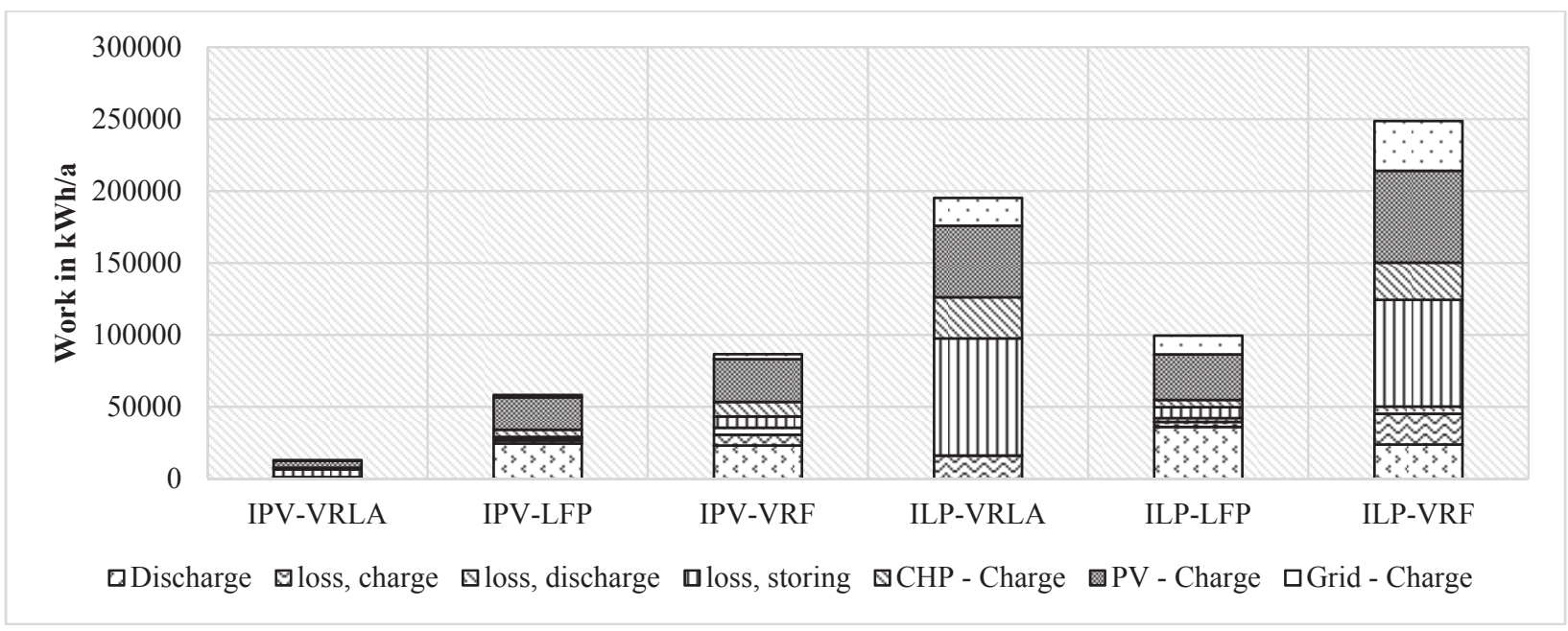




\section{Dispatch Optimisation - Scenario II}

Comparing the two base scenarios additional 106,054 kWh per year are consumed in scenario II due to the electricity consumption of the electric vehicles. This extra demand is mostly covered by electricity from the grid, which almost doubles, followed by CHP and PV generation with an increase of 14,688 and $8,813 \mathrm{kWh}$ per year respectively.

The utilisation of the VRLA system shows the same results as in scenario I and is not further analysed. Again, the energy system using the LFP battery system generates the lowest amount of electricity and decreases the generation by $21,998 \mathrm{kWh}$ compared to the base scenario. Grid delivered electricity accounts for $141,306 \mathrm{kWh}$ and is the lowest value achieved in scenario II. A high utilised electricity share of PV and CHP generation increases the degree of self-supply by $9 \%$ and autarky by $5 \%$ compared to the base scenario. The VRF battery system reduces the overall electricity generation by 9,942 kWh and utilises the highest share of CHP and PV generation. It reaches the same value for selfsupply degree but a lower value for the autarky degree (63\%) compared to the LFP battery system. A summary of the results is displayed in FIGURE 5.

The ESS performances are displayed in FIGURE 6. PV electricity is mostly stored in the ESS followed by CHP and grid electricity. The VRF, which suffers from the lowest total efficiency, exhibits the highest losses. The highest efficiency regarding discharge - charge ratio reaches the LFP system in scenario IIPV with $85 \%$, whereas the VRF system reaches $54 \%$. Utilising the LFP battery system the CHP generation increases to $20.4 \mathrm{~kW}$. The CHP is again charging electricity into the battery during winter periods, when electricity generation from PV is decreasing and EPEX prices are high. This occurs, when the CHP cannot provide enough electricity to cover the entire demand. Compared to scenario I those periods increased slightly. For the entire year the electricity supplied by the grid increased compared to scenario I, resulting in no periods of self-supply. During winter periods grid electricity supply again increases due to lower PV generation. Noticeable are again peaks of grid electricity supply due to low electricity prices. The average grid electricity charge power accounts for $0.25 \mathrm{~kW}$ over the year. The PV grid feed-in starting point can be delayed again. The average PV power charge rate accounts for $3.1 \mathrm{~kW}$ over the year.

Utilising the VRF system, almost the same yearly curve occurs, showing a slightly higher charge of PV electricity into the battery over the year. The average electricity power of CHP increases to $20.6 \mathrm{~kW}$. $\mathrm{PV}$ and grid electricity are charged into the battery with an average power of $3.5 \mathrm{~kW}$ and $0.6 \mathrm{~kW}$ respectively.

Scenario IILP shows a tremendous increase in grid electricity consumption of $28,706 \mathrm{kWh}$ for the VRLA and $37,335 \mathrm{kWh}$ for the VRF system. Only the LFP system reduces the grid electricity consumption by $11,922 \mathrm{kWh}$. The VRLA and VRF systems store higher amounts of electricity generated by PV and CHP to cover their efficiency losses. This results in higher self-supply rates, when battery losses are considered as demand. LFP and VRF system are able to deliver a significantly higher amount of electricity than in scenario IIPV, which leads to an increase in the degree of autarky $(+6 \%)$ and self-supply $(+7 \%)$ at least for the LFP system. The self-supply degree of the VRF system increases by $4 \%$ as the total losses are increasing as well. The autarky degree decreases to 57\%. Only the LFP system can reduce total electricity demand significantly by utilising generated PV electricity. All results are summarized in TABLE 3.

The analysed yearly demand curve exhibits higher charge power into the ESS by the electricity grid, especially during price periods when prices falling to $0 €$ cent per $\mathrm{kWh}$. 
FIGURE 5

\section{SCENARIO II - UTILISED ELECTRICITY GENERATION FOR DEMAND COVERING}

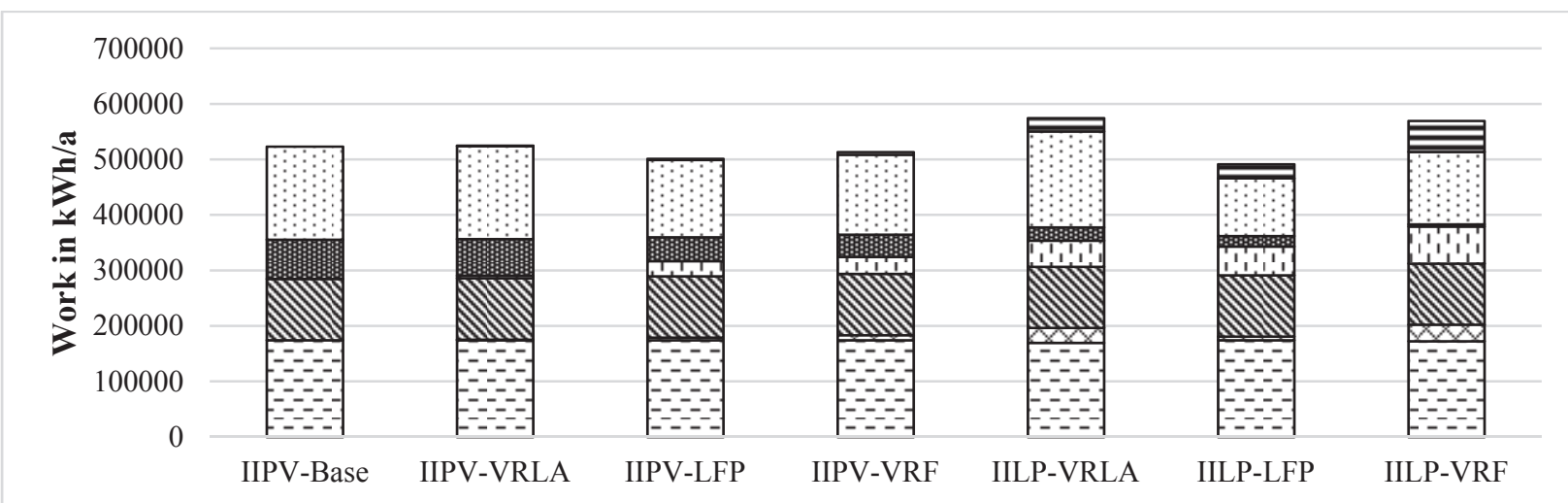

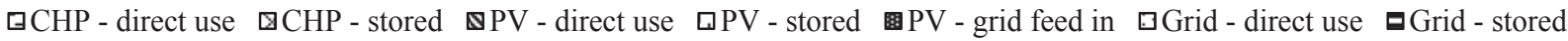

FIGURE 6

SCENARIO II - STORAGE CHARGE/DISCHARGE PERFORMANCE

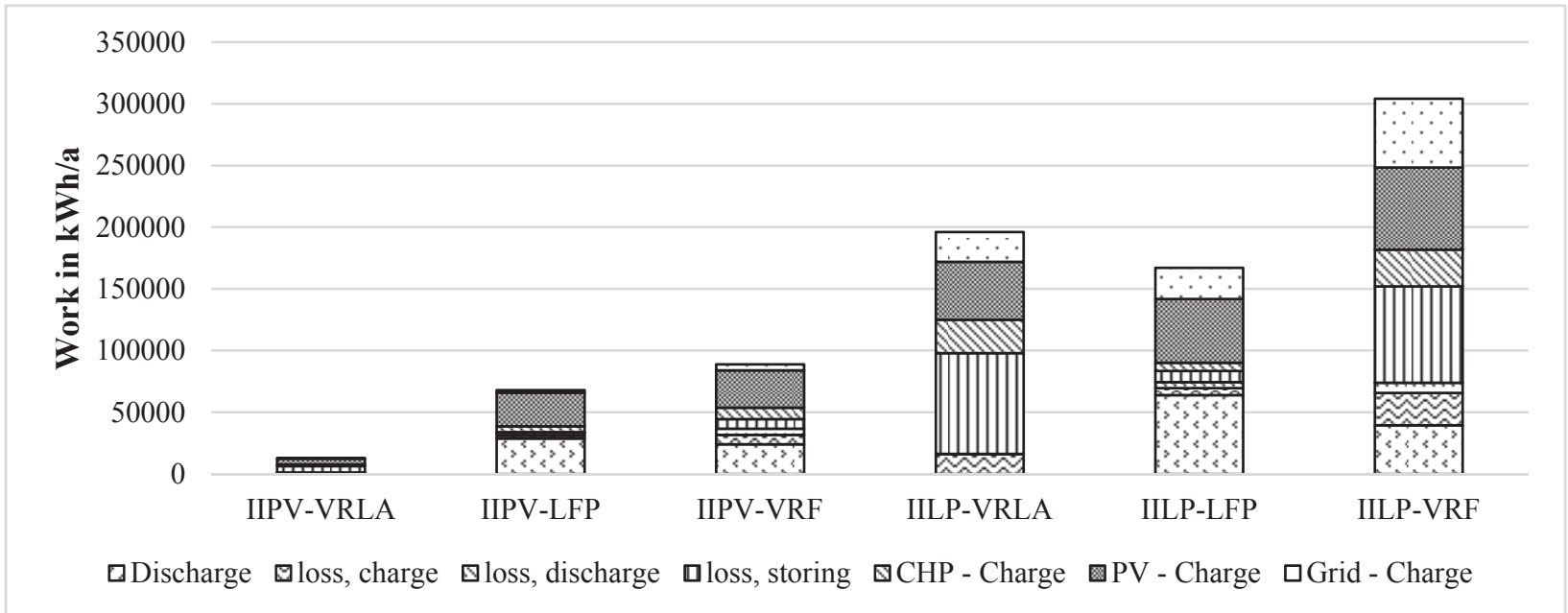

\section{Dispatch Optimisation - Scenario III}

In general, the designed energy model is not able to sustain autarky. All three ESS can reach selfsupply degrees over $76 \%$ and autarky degrees over $87 \%$ for the analysed capacities in IIIPV and IIILP. Autarky periods during the year can be seen during periods of high PV electricity generation mainly in the middle of the year for all ESS. Although the VRLA and VRF systems are competitive compared to the LFP system in scenario IIIPV they lose ground in scenario IIILP caused by high losses during electricity storing (See FIGURE 7). As the LFP system achieves the highest values of self-supply (86\%) and autarky degree (90\%) in IIILP it is closer analysed. The lowest amount of emergency electricity and electricity consumption is reached utilising the LFP battery system in IIILP. The LFP storage behaviour in IIILP shows a decrease of electricity generation of $5,880 \mathrm{kWh}$ per year and an increase of storage losses of $10,400 \mathrm{kWh}$ compared to IIIPV. The losses are mainly covered by PV electricity, which utilisation increases by $16,280 \mathrm{kWh}$. The total amount supplied by the emergency generation decreases by $12,976 \mathrm{kWh}$. 
The ESS performances are displayed in FIGURE 8. PV electricity is mostly stored in the ESS followed by CHP. The VRF exhibits the highest losses. The highest efficiency regarding discharge charge ratio reaches the LFP system in scenario IIILP with 75\%.

\section{FIGURE 7 \\ SCENARIO III - UTILISED ELECTRICITY GENERATION FOR DEMAND COVERING}

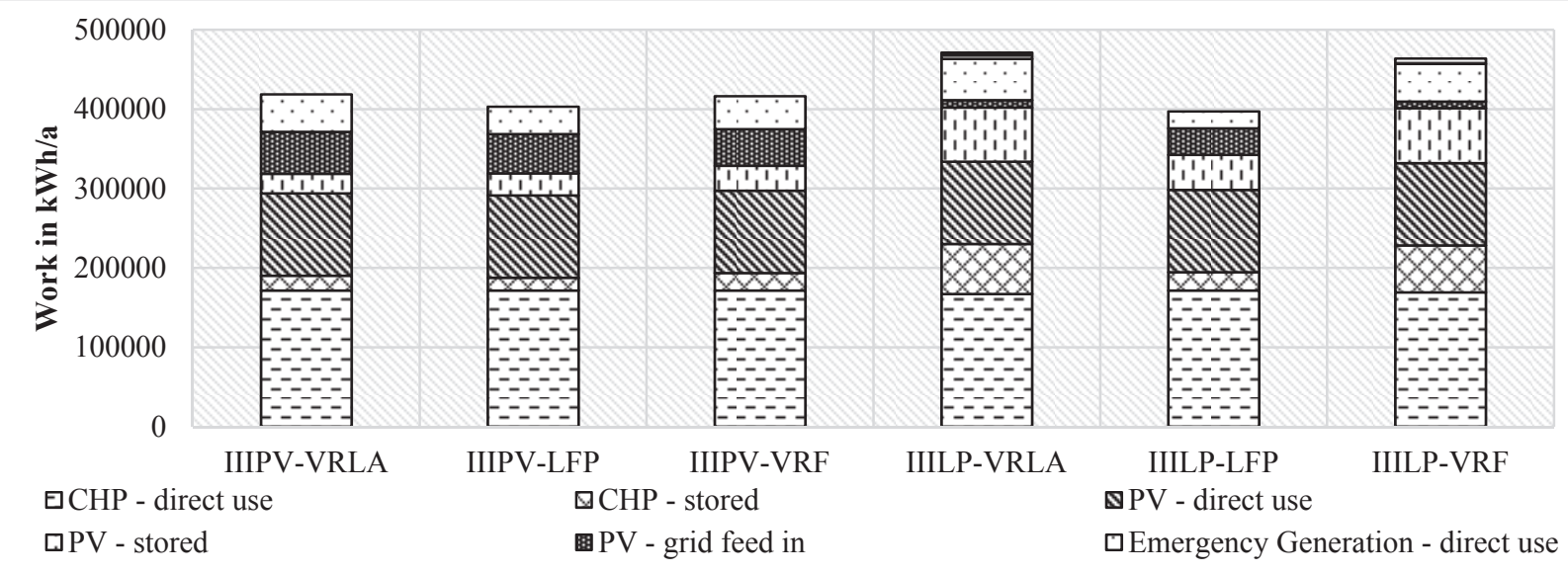

\section{FIGURE 8 \\ SCENARIO III - STORAGE CHARGE/DISCHARGE PERFORMANCE}

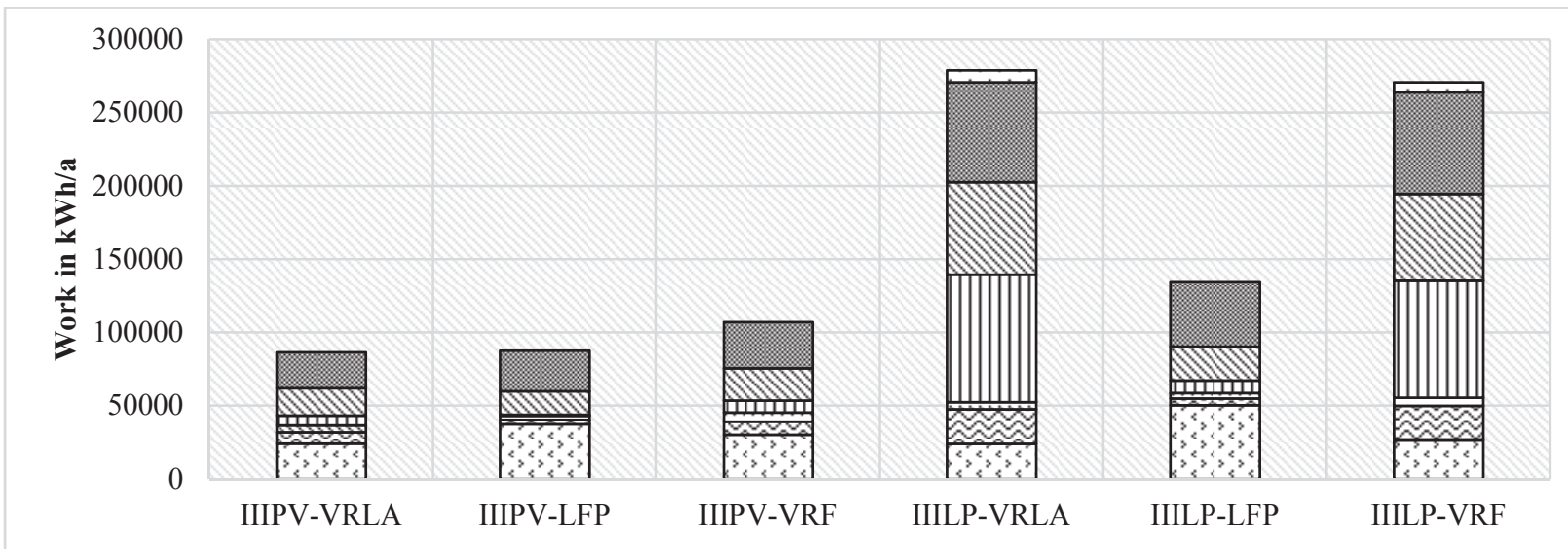

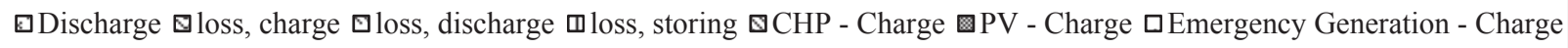

\section{Life Cycle Assessment}

When discharging $1 \mathrm{MWh}$ out of the ESS different installed capacities and masses are necessary due to different efficiencies and energy densities respectively. The highest mass achieves the VRLA due to its low energy density and LTspez. The low LTspez leads to high replacement rates thus to a high amount of total installed capacity to provide the $1 \mathrm{MWh}$. The high LTspez of VRF results in a low installed capacity but caused by the low energy density the mass is still higher than the mass of the LFP (See TABLE 2). The mass has a high impact on the impact category resources as depicted in FIGURE 9. The high utilised mass of VRLA results in a total resource depletion of $3.26 \mathrm{~kg} \mathrm{Sb}-\mathrm{Eq}$ and is significantly higher than the values for LFP $(0.02 \mathrm{~kg} \mathrm{Sb}-\mathrm{Eq})$ and VRF $(0.01 \mathrm{~kg} \mathrm{Sb}-\mathrm{Eq})$ and primarily caused by the lead production. The amount for LFP is to $60 \%$ based on the production of the BMS. The production of the VRF battery module contributes $40 \%$ to the total impact. For the impact category climate change most impacts occur 
due to electricity losses of the ESS, whereas LFP emitting the lowest total amount of $\mathrm{kg}$ CO2-Eq followed by VRF and VRLA (See FIGURE 11). The highest share of impacts in the battery system production hold cell production for LFP (15\% of the total emissions). For VRF the highest impact is caused by the electrolyte production ( $15 \%$ of the total emissions) whereas the lead production is primarily causing most impacts during production for the VRLA battery system. The emissions for climate change for the analysed ESS are in line with recent literature (Baumann et al., 2017; Spanos et al., 2015; Weber et al., 2018). Electricity losses contribute highly to the impact of freshwater ecotoxicity (See FIGURE 10). Again, the high amount of lead results in a high impact during lead production for the VRLA. The cell production for the LFP is main driver of the impact category ( $21 \%$ of total emissions), whereas the electrolyte production for the VRF battery module is emitting the most impacts for the VRF (14\% of total emissions).

TABLE 2

ESS CAPACITIES AND MASSES

\begin{tabular}{|c|c|c|c|}
\hline ESS & VRLA & LFP & VRF \\
\left.\hline${\text { Capacity }\left[\mathrm{kWh}_{\text {inst }}\right]}\right]$ & 1.65 & 0.30 & 0.15 \\
\hline Mass $[\mathrm{kg}]$ & 47 & 3 & 6 \\
\hline
\end{tabular}

FIGURE 9

RESULTS FOR RESOURCES-MINERAL, FOSSILS AND RENEWABLES

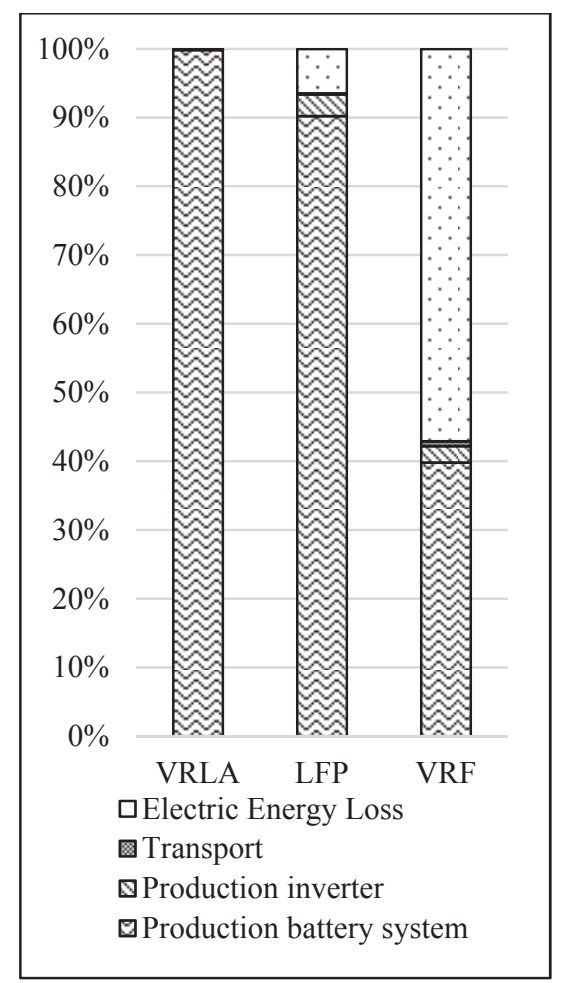


FIGURE 10

RESULTS FOR ECOSYSTEM QUALITY-FRESHWATER ECOTOXICITY

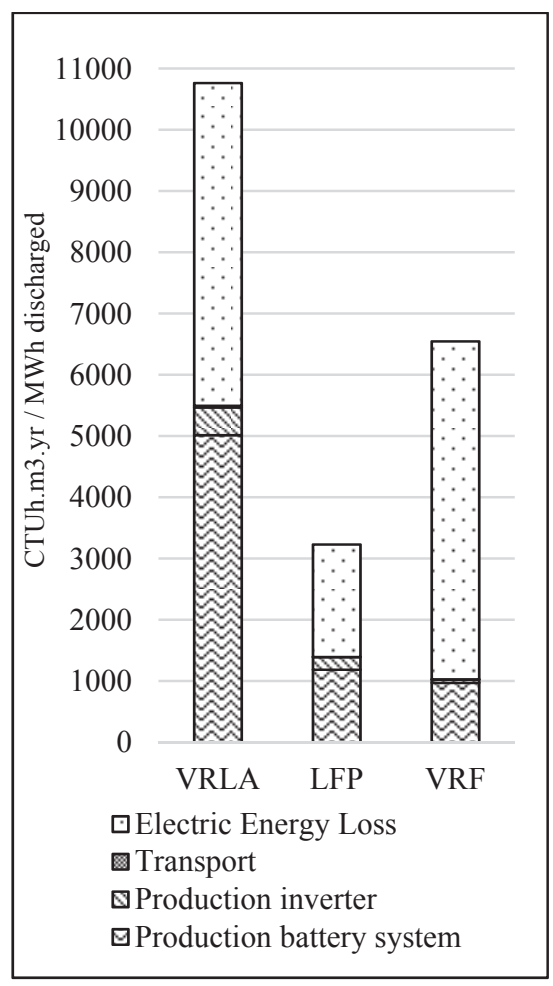

FIGURE 11

RESULTS FOR CLIMATE CHANGE

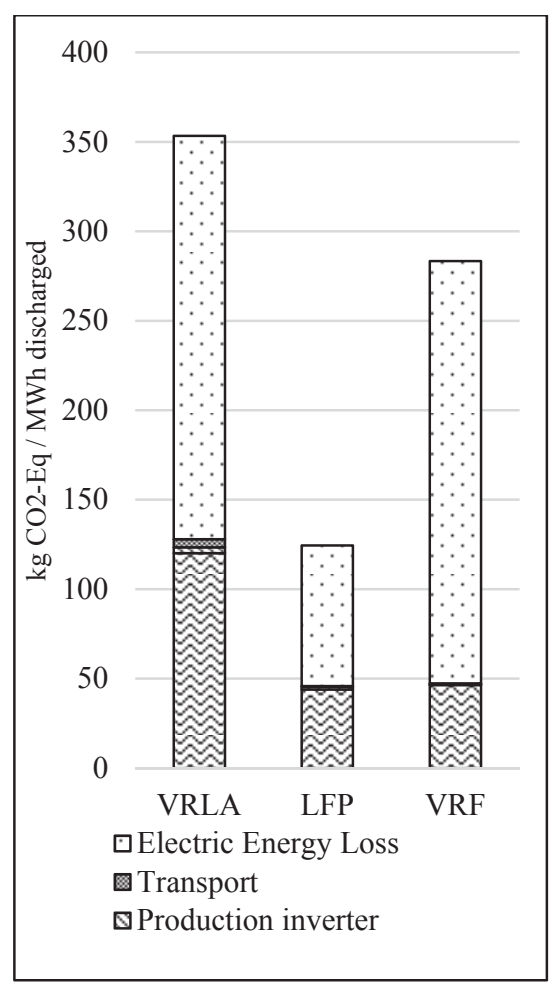

70 Journal of Strategic Innovation and Sustainability Vol. 14(6) 2019 


\section{CONCLUSIONS}

Generally, the LFP battery system shows the best constellation of variable costs, energy density, efficiencies and lifetime. It is followed by the VRF system on condition the installed capacity is 182 $\mathrm{kWh}_{\text {inst }}$ Then it is achieving similar degrees of self-supply and autarky when applied in the energy system model. Consequently, those ESS in combination with PV and CHP are competitive with the EPEX spot market under the taken assumptions in a grid connected system. The VRLA system is almost not operated during the analysed year caused by its low cycle life and high battery degradation costs respectively. High cycle life of LFP and VRF compensates their high specific costs per installed kilowatt-hours. Due to the low battery degradation costs those ESS are operated more often during the analysed year. They are reaching only low amounts of used lifetime throughput, which is in line that a stationary application is less stressful for ESS. Thus, making the assumption of considering only $20 \%$ of replacement costs more likely. But it is questioning the approach only considering battery degradation costs based on cycle aging as the calendric aging might have more influence.

In scenario I too high installed capacities in the grid connected system are not recommended as they only increase storage losses. However, an increasing demand due to BEVs can make an extension of storage capacity useful. Consequently, both demand curve and supply curve are decisive for the optimal storage capacity, as it can assist to compensate the daily shift of demand and PV supply. Self-discharge rates per hour are decisive for ESS with high capacities. Thus, making the VRF system the more recommended system for hourly energy shift due its high storage losses. The LFP system shows potential being a daily storage system for instance in off-grid situations as it is able to store electricity over time more efficiently. It is noticeable, that a significant increase of storage capacity only results in little increases of the degrees of self-supply and autarky, which is in line with Waffenschmidt (2014) and Weniger and Quaschning (2013).

The analysed ESS are not able to maintain autarky in the analysed system as the summer winter discrepancy cannot be closed. The LFP reaches the highest autarky degree in the off-grid scenario with an installed capacity of $2,850 \mathrm{kWh}_{\text {inst }}$. Combined with long-term storage system with low self- discharge rates autarky might be possible. VRF and VRLA suffer from high inefficiencies in scenario III. Thus, they are not recommended for high capacities in off-grid scenarios as they need extra supply to maintain their minimum state of charge.

The VRLA shows the highest impacts in all assessed categories due to its low energy density and low cycle life, which is significantly increasing the lead demand. The carbon dioxide emissions in the production phase of VRF and LFP are almost the same. During the use phase the high inefficiencies of the VRF system are contributing mainly to its impact. Substituting the European electricity mix with an electricity generation from renewables will reduce impacts due to losses for all three systems and all impact categories. Consequently, the source of electricity is an important criterion, when analysing the use phase of batteries. An increase of efficiency of the VRF system will result in an improvement in the categories of climate change and freshwater ecotoxicity. The LFP battery system consumes a higher amount of resources compared to the VRF system. The LFP system is able to store electricity with lower losses consequently its application is recommended in situations electricity is a scarce good. When electricity is over produced, for instance by PV, the VRF is recommended due to its lower variable costs and lower resource depletion.

\section{ACKNOWLEDGEMENT}

This article first appeared in the proceedings of the 16th IAEE Conference. 


\section{REFERENCES}

Argent-Katwala, A., Dingle, N. J., \& Harder, U. (2009). 24th UK Performance Engineering Workshop: 34 July 2008, Department of Computing, Imperial College, London. Departmental technical reports: DTR08-9. Nottingham: Department of Computing, Imperial College London.

ASUE e.V. (2011, June). BHKW-Kenndaten 2011: Module, Anbieter, Kosten. Frankfurt am Main. Retrieved from https://www.asue.de/blockheizkraftwerke/broschueren/05_07_11_bhkwkenndaten_-_2011

Barteczko-Hibbert, C., Bonis, I., Binns, M., Theodoropoulos, C., \& Azapagic, A. (2014). A multi-period mixed-integer linear optimisation of future electricity supply considering life cycle costs and environmental impacts. Applied Energy, 133, 317-334.

https://doi.org/10.1016/j.apenergy.2014.07.066

Bauer, C. (2010). Ökobilanz von Lithium-Ionen Batterien. Villingen.

Baumann, M., Peters, J. F., Weil, M., \& Grunwald, A. (2017). CO 2 Footprint and Life-Cycle Costs of Electrochemical Energy Storage for Stationary Grid Applications. Energy Technology, 5(7), 1071-1083. https://doi.org/10.1002/ente.201600622

Beer, B. de, \& Rix, A. (2016). Influences of Energy Throughput on the Life of Various Battery Technologies. In 4th Southern African Solar Energy Conference (SASEC).

Bindner, H. (2005). Lifetime modelling of lead acid batteries. Risø R, Report: Vol. 1515. Roskilde: Risø National Laboratory. Retrieved from http://iis-03.risoe.dk/netahtml/risoe/publ_uk.htm

Bobba, S., Mathieux, F., Ardente, F., Blengini, G. A., Cusenza, M. A., Podias, A., \& Pfrang, A. (2018). Life Cycle Assessment of repurposed electric vehicle batteries: an adapted method based on modelling energy flows. Journal of Energy Storage, 19, 213-225. https://doi.org/10.1016/j.est.2018.07.008

Bordin, C. (2015). Mathematical Optimization Applied to Thermal and Electrical Energy Systems (Dissertation). Universita di Bologna, Bologna. Retrieved from http://amsdottorato.unibo.it/6915/1/Bordin_Chiara_tesi.pdf

Bordin, C., Anuta, H. O., Crossland, A., Gutierrez, I. L., Dent, C. J., \& Vigo, D. (2017). A linear programming approach for battery degradation analysis and optimization in offgrid power systems with solar energy integration. Renewable Energy, 101, 417-430. https://doi.org/10.1016/j.renene.2016.08.066

Bundesnetzagentur. (2018). Datenmeldungen vom 1. Juli 2017 bis 30. November 2018. Retrieved from https:/www.bundesnetzagentur.de/DE/Sachgebiete/ElektrizitaetundGas/Unternehmen_Institution en/ErneuerbareEnergien/ZahlenDatenInformationen/EEG_Registerdaten/EEG_Registerdaten_no de.html

Chedid, R., \& Rahman, S. (1997). Unit sizing and control of hybrid wind-solar power systems. IEEE Transactions on Energy Conversion, 12(1), 79-85. https://doi.org/10.1109/60.577284

Chen, S. X., \& Gooi, H. B. (2010, June). Sizing of energy storage system for microgrids. In 2010 IEEE 11th International Conference on Probabilistic Methods Applied to Power Systems (pp. 6-11). IEEE. https://doi.org/10.1109/PMAPS.2010.5528720

Deutsches Institut für Normung e.V. (2018). Umweltmanagement - Ökobilanz-Anforderungen und Anleitungen (ISO 14044:2006 + Amd 1:2017); Deutsche Fassung EN ISO 14044:2006 + A1:2018. (Norm, DIN EN ISO 14044). Berlin: Beuth Verlag GmbH.

Deutsches Institut für Normung e.V. (2019). Umweltmanagement -Ökobilanz - Grundsätze und Rahmenbedingungen (ISO 14040:2006) Deutsche und Englische Fassung EN ISO 14040:2006. (Norm, DIN EN ISO 14040). Berlin: Beuth Verlag GmbH.

Ellingsen, L. A-W., Majeau-Bettez, G., Singh, B., Srivastava, A. K., Valøen, L. O., \& Strømman, A. H. (2014). Life Cycle Assessment of a Lithium-Ion Battery Vehicle Pack. Journal of Industrial Ecology, 18(1), 113-124. https://doi.org/10.1111/jiec.12072

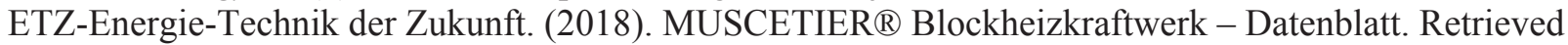
from https:/etz-energietechnik.com/wp-content/uploads/2018/09/Datenblatt-Muscetier-2018.pdf

72 Journal of Strategic Innovation and Sustainability Vol. 14(6) 2019 
European Commission. (2017). PHOTOVOLTAIC GEOGRAPHICAL INFORMATION SYSTEM.

Retrieved from http://re.jrc.ec.europa.eu/pvg_tools/en/tools.html

European Commission, Joint Research Centre, Renewable Energies Unit. (2006). ENERGY RATING OF PV MODULES BASED ON PVGIS IRRADIANCE AND TEMPERATURE DATABASE. 21st European Photovoltaic Solar Energy Conference, 2088-2092.

Eurostat. (n.d.). Electricity generation statistics. Retrieved from https://ec.europa.eu/eurostat/statisticsexplained/images/7/73/Electricity_Statistics_Files\%2C_2017_\%28GWh\%29-1-update-23-042018.xlsx

Eurostat. (n.d.). Road freight transport by journey characteristics. Retrieved from https://ec.europa.eu/eurostat/statistics-

explained/index.php/Road_freight_transport_by_journey_characteristics\#Average_distance_trave lled

Eurostat. (2017). Energy balance sheets: 2015 DATA (2017 edn.). Luxembourg: Publications Office of the European Union. Retrieved from https://ec.europa.eu/eurostat/documents/3217494/8113778/KS-EN-17-001-EN-N.pdf/99cc20f1cb11-4886-80f9-43ce0ab7823c https://doi.org/10.2785/032728

Hall, L. M.H., \& Buckley, A. R. (2016). A review of energy systems models in the UK: Prevalent usage and categorisation. Applied Energy, 169, 607-628. https://doi.org/10.1016/j.apenergy.2016.02.044

Hauschild, M. Z., Goedkoop, M., Guinée, J., Heijungs, R., Huijbregts, M., Jolliet, O., . . Pant, R. (2013). Identifying best existing practice for characterization modeling in life cycle impact assessment. The International Journal of Life Cycle Assessment, 18(3), 683-697. https://doi.org/10.1007/s11367-012-0489-5

Heinz, D. (2018). Erstellung und Auswertung repräsentativer Mobilitäts- und Ladeprofile für Elektrofahrzeuge in Deutschland (Bachelorthesis). Karlsruher Institut für Technologie, Karlsruhe. Retrieved from https://www.iip.kit.edu/english/3559.php https://doi.org/10.5445/IR/1000086372

Hilpert, S., Kaldemeyer, C., Krien, U., Günther, S., Wingenbach, C., \& Plessmann, G. (2018). The Open Energy Modelling Framework (oemof) - A new approach to facilitate open science in energy system modelling. Energy Strategy Reviews, 22, 16-25. https://doi.org/10.1016/j.esr.2018.07.001

Hörner, M. (12.2013). Brennstoff-Allokation bei der Kraft-Wärme-Kopplung: DIN NA 041-05-01 NHRS Ad hoc Arbeitsgruppe KWK-Bewertung. Darmstadt.

Huneke, F., Henkel, J., Benavides González, J. A., \& Erdmann, G. (2012). Optimisation of hybrid offgrid energy systems by linear programming. Energy, Sustainability and Society, 2(1), 1-19. https://doi.org/10.1186/2192-0567-2-7

International reference life cycle data system (ILCD) handbook: General guide for life cycle assessment: provisions and action steps (1st edn.). (2011). EUR, Scientific and technical research series: Vol. 24571. Luxembourg: Publications Office.

IZES gGmbH. (2012). Forschungsbericht Praxistest "Moderne Energiesparsysteme im Haushalt". Retrieved from http://www.izes.de/sites/default/files/publikationen/EM_8_705.pdf

Jongerden, M. R., \& Haverkort, B. R. (2017). Battery Aging, Battery Charging and the Kinetic Battery Model: A First Exploration. In N. Bertrand \& L. Bortolussi (Eds.), Lecture Notes in Computer Science. Quantitative Evaluation of Systems (Vol. 10503, pp. 88-103). Cham: Springer International Publishing. https://doi.org/10.1007/978-3-319-66335-7_6

Kaltschmitt, M., Streicher, W., \& Wiese, A. (2013). Erneuerbare Energien. Berlin, Heidelberg: Springer Berlin Heidelberg. https://doi.org/10.1007/978-3-642-03249-3

Kazemi, S. M., \& Rabbani, M. (2013). An Integrated Decentralized Energy Planning Model considering Demand-Side Management and Environmental Measures. Journal of Energy, 2013(4), 1-6. https://doi.org/10.1155/2013/602393

Keil, P., Schuster, S. F., Lüders, C. von, \& Hesse, H. (2015). Lifetime Analyses of Lithium-Ion EV Batteries. 3rd Electromobility Challenging Issues conference (ECI), Singapore, 1st-4th December. 
Konstantin, P. (2017). Praxisbuch Energiewirtschaft. Berlin, Heidelberg: Springer Berlin Heidelberg. https://doi.org/10.1007/978-3-662-49823-1

Krieger, E. M., Cannarella, J., \& Arnold, C. B. (2013). A comparison of lead-acid and lithium-based battery behavior and capacity fade in off-grid renewable charging applications. Energy, 60, 492500. https://doi.org/10.1016/j.energy.2013.08.029

Kriett, P. O., \& Salani, M. (2012). Optimal control of a residential microgrid. Energy, 42(1), 321-330. https://doi.org/10.1016/j.energy.2012.03.049

Majeau-Bettez, G., Hawkins, T. R., \& Strømman, A. H. (2011). Life cycle environmental assessment of lithium-ion and nickel metal hydride batteries for plug-in hybrid and battery electric vehicles.

Environmental Science \& Technology, 45(10), 4548-4554. https://doi.org/10.1021/es103607c

Manfren, M. (2012). Multi-commodity network flow models for dynamic energy management Mathematical formulation. Energy Procedia, 14, 1380-1385. https://doi.org/10.1016/j.egypro.2011.12.1105

McManus, M. C. (2012). Environmental consequences of the use of batteries in low carbon systems: The impact of battery production. Applied Energy, 93, 288-295.

https://doi.org/10.1016/j.apenergy.2011.12.062

Mustonen, S., \& Nanthavong, K. (2006). Modeling of autonomous power systems - A mathematical model of a hybrid power system. In Proceedings of the 2nd Joint International Conference on "Sustainable Energy and Environment (SEE 2006)" 21-23 November, 2006, Bangkok, Thailand.

Naumann, M., Karl, R. C., Truong, C. N., Jossen, A., \& Hesse, H. C. [Holger] (2015). Lithium-ion Battery Cost Analysis in PV-household Application. Energy Procedia, 73, 37-47. https://doi.org/10.1016/j.egypro.2015.07.555

Notter, D. A., Gauch, M., Widmer, R., Wäger, P., Stamp, A., Zah, R., \& Althaus, H.- J. (2010). Contribution of Li-ion batteries to the environmental impact of electric vehicles. Environmental Science \& Technology, 44(17), 6550-6556. https://doi.org/10.1021/es903729a

Oemof-Team. (2019, January). oemof documentation. Retrieved from https://media.readthedocs.org/pdf/oemof/latest/oemof.pdf

Peters, J., Baumann, M. [Manuel], Zimmermann, B., Braun, J., \& Weil, M. [Marcel] (2017). The environmental impact of Li-Ion batteries and the role of key parameters - A review. Renewable and Sustainable Energy Reviews, 67, 491-506. https://doi.org/10.1016/j.rser.2016.08.039

Peters, J., Buchholz, D., Passerini, S., \& Weil, M. [Marcel] (2016). Life cycle assessment of sodium-ion batteries. Energy \& Environmental Science, 9(5), 1744-1751. https://doi.org/10.1039/C6EE00640J

Peters, J., \& Weil, M. [Marcel] (2018). Providing a common base for life cycle assessments of Li-Ion batteries. Journal of Cleaner Production, 171, 704-713. https://doi.org/10.1016/j.jclepro.2017.10.016

Peterson, S. B., Whitacre, J. F., \& Apt, J. (2010). The economics of using plug-in hybrid electric vehicle battery packs for grid storage. Journal of Power Sources, 195(8), 2377-2384. https://doi.org/10.1016/j.jpowsour.2009.09.070

Puri, A. (2013, July). Optimally sizing battery storage and renewable energy sources on an off-grid facility. In 2013 IEEE Power \& Energy Society General Meeting (pp. 1-5). IEEE. https://doi.org/10.1109/PESMG.2013.6672204

Ramoni, M. O., \& Zhang, H.-C. (2013). End-of-life (EOL) issues and options for electric vehicle batteries. Clean Technologies and Environmental Policy, 15(6), 881-891. https://doi.org/10.1007/s10098-013-0588-4

Rauner, S., \& Budzinski, M. (2017). Holistic energy system modelling combining multi-objective optimization and life cycle assessment. Environmental Research Letters, 12(12), 1-13. https://doi.org/10.1088/1748-9326/aa914d

74 Journal of Strategic Innovation and Sustainability Vol. 14(6) 2019 
Reid, G., \& Julve, J. (2016). Second Life-Batteries As Flexible Storage For Renewables Energies. Retrieved from https://www.bee-ev.de/fileadmin/Publikationen/Studien/201604_Second_LifeBatterien_als_flexible_Speicher.pdf

Rydh, C. J., \& Sandén, B. A. (2005). Energy analysis of batteries in photovoltaic systems. Part I: Performance and energy requirements. Energy Conversion and Management, 46(11-12), 1957 1979. https://doi.org/10.1016/j.enconman.2004.10.003

Samsatli, S., \& Samsatli, N. J. (2018). A general mixed integer linear programming model for the design and operation of integrated urban energy systems. Journal of Cleaner Production, 191, 458-479. https://doi.org/10.1016/j.jclepro.2018.04.198

Schäuble, J., Kaschub, T., Ensslen, A., Jochem, P., \& Fichtner, W. (2017). Generating electric vehicle load profiles from empirical data of three EV fleets in Southwest Germany. Journal of Cleaner Production, 150, 253-266. https://doi.org/10.1016/j.jclepro.2017.02.150

Spanos, C., Turney, D. E., \& Fthenakis, V. (2015). Life-cycle analysis of flow-assisted nickel zinc-, manganese dioxide-, and valve-regulated lead-acid batteries designed for demand-charge reduction. Renewable and Sustainable Energy Reviews, 43, 478-494. https://doi.org/10.1016/j.rser.2014.10.072

Stadler, M., Marnay, C., Kloess, M., Cardoso, G., Mendes, G., Siddiqui, A., . . Lai, J. (2012). Optimal Planning and Operation of Smart Grids with Electric Vehicle Interconnection. Journal of Energy Engineering, 138(2), 95-108. https://doi.org/10.1061/(ASCE)EY.1943-7897.0000070

Sterner, M., \& Stadler, I. (Eds.). (2017). Energiespeicher - Bedarf, Technologien, Integration (2. korrigierte und ergänzte Auflage). Berlin: Springer Vieweg. Retrieved from http://dx.doi.org/10.1007/978-3-662-48893-5 https://doi.org/10.1007/978-3-662-48893-5

Technisches Datenblatt. Retrieved from https://voltstorage.com

Tjaden, T., Bergner, J., Weniger, J., \& Quaschning, V. (2015, November). Repräsentative elektrische Lastprofile für Wohngebäude in Deutschland auf 1-sekündiger Datenbasis. https://doi.org/10.13140/RG.2.1.5112.0080

Trojan Battery Company, L. L.C. SAGM 12 205. Retrieved from $\mathrm{http}: / /$ www.trojanbattery.com/pdf/SAGM_12_205_AGM_DS.pdf

Trojan Battery Company, L. L.C. TR 12.8-92 Li-ion. Retrieved from https://www.trojanbattery.com/pdf/datasheets/24_Lithium_12.8-92.pdf

Upadhyay, S., \& Sharma, M. P. (2013, April). Optimization of hybrid energy system for off-grid application. In 2013 International Conference on Energy Efficient Technologies for Sustainability (pp. 343-348). IEEE. https://doi.org/10.1109/ICEETS.2013.6533407

Volkart, K., Mutel, C. L., \& Panos, E. (2018). Integrating life cycle assessment and energy system modelling: Methodology and application to the world energy scenarios. Sustainable Production and Consumption, 16, 121-133. https://doi.org/10.1016/j.spc.2018.07.001

Waffenschmidt, E. (2014). Dimensioning of Decentralized Photovoltaic Storages with Limited Feed-in Power and their Impact on the Distribution Grid. Energy Procedia, 46, 88-97. https://doi.org/10.1016/j.egypro.2014.01.161

Weber, S., Peters, J. F. [Jens F.], Baumann, M. [Manuel], \& Weil, M. [Marcel] (2018). Life Cycle Assessment of a Vanadium Redox Flow Battery. Environmental Science \& Technology, 52(18), 10864-10873. https://doi.org/10.1021/acs.est.8b02073

Weniger, J., \& Quaschning, V. (2013, March). Begrenzung der Einspeiseleistung von netzgekoppelten Photovoltaiksystemen mit Batteriespeichern, 28. Symposium Photovoltaische Solarenergie. Retrieved from https://pvspeicher.htw-berlin.de/wp-content/uploads/2014/04/STAFFELSTEIN2013-Begrenzung-der-Einspeiseleistung-von-netzgekoppelten-Photovoltaiksystemen-mitBatteriespeichern.pdf

Wernet, G., Bauer, C. [Christian], Steubing, B., Reinhard, J., Moreno-Ruiz, E., \& Weidema, B. (2016). The ecoinvent database version 3 (part I): overview and methodology. The International Journal of Life Cycle Assessment, 21(9), 1218-1230. https://doi.org/10.1007/s11367-016-1087-8 
Wiese, F., Hilpert, S. [Simon], Kaldemeyer, C. [Cord], \& Pleßmann, G. (2018). A qualitative evaluation approach for energy system modelling frameworks. Energy, Sustainability and Society, 8(1), 116. https://doi.org/10.1186/s13705-018-0154-3

Wingenbach, C., Hilpert, S., \& Kaldemeyer, C. (2017, June). Entwicklung eines Open Source EnergieModells für Schleswig-Holstein (openMod.sh). Flensburg. Retrieved from Zentrum für nachhaltige Energiesysteme (ZNES) website: https://www.uniflensburg.de/fileadmin/content/abteilungen/industrial/dokumente/downloads/veroeffentlichungen/ forschungsergebnisse/openmodsh-endbericht-1.pdf

Yoshida, A., Sato, T., Amano, Y., \& Ito, K. (2016). Impact of electric battery degradation on cost- and energy-saving characteristics of a residential photovoltaic system. Energy and Buildings, 124, 265-272. https://doi.org/10.1016/j.enbuild.2015.08.036

Zackrisson, M., Avellán, L., \& Orlenius, J. (2010). Life cycle assessment of lithium-ion batteries for plug-in hybrid electric vehicles - Critical issues. Journal of Cleaner Production, 18(15), 1519 1529. https://doi.org/10.1016/j.jclepro.2010.06.004

Zhang, L., Barakat, G., \& Yassine, A. (2012). Deterministic optimization and cost analysis of hybrid pv/wind/battery/diesel power system. International Journal of Renewable Energy Research, 2. 


\section{APPENDIX}

TABLE 1

SCENARIO I RESULT

\begin{tabular}{|c|c|c|c|c|c|c|c|}
\hline electricity ge ne ration [kWh/a] & IPV-Base & IPV-VRLA & IPV-LFP & IPV-VRF & ILP-VRLA & ILP-LFP & ILP-VRF \\
\hline Total & 426,171 & 427,669 & 408,204 & 416,638 & 474,373 & 408,236 & 462,830 \\
\hline CHP - total & 159,764 & 160,949 & 164,712 & 169,701 & 184,444 & 164,836 & 184,010 \\
\hline CHP - direct use & 159,764 & 159,759 & 159,740 & 159,595 & 155,873 & 159,764 & 158,138 \\
\hline CHP - stored & - & 1,190 & 4,972 & 10,106 & 28,571 & 5,072 & 25,872 \\
\hline $\mathrm{PV}$ - total & 181,074 & 181,074 & 181,074 & 181,074 & 181,074 & 181,074 & 181,074 \\
\hline PV-used & 101,739 & 106,566 & 124,235 & 131,414 & 151,140 & 133,382 & 165,588 \\
\hline$P V$ - direct use & 101,739 & 101,713 & 101,737 & 101,702 & 101,365 & 101,740 & 101,620 \\
\hline PV - stored & - & 4,853 & 22,498 & 29,711 & 49,775 & 31,641 & 63,968 \\
\hline$P V$ - grid feed in & 79,335 & 74,508 & 56,840 & 49,661 & 29,934 & 47,693 & 15,486 \\
\hline Grid - total & 85,333 & 85,646 & 62,417 & 65,862 & 108,854 & 62,325 & 97,745 \\
\hline Grid - direct use & 85,333 & 85,184 & 60,746 & 62,341 & 89,554 & 49,224 & 63,177 \\
\hline Grid - stored & - & 463 & 1,672 & 3,521 & 19,300 & 13,101 & 34,568 \\
\hline electricity s tore d $[\mathrm{kWh} / \mathrm{a}]$ & IPV-Base & IPV-VRLA & IPV-LFP & IPV-VRF & ILP-VRLA & ILP-LFP & ILP-VRF \\
\hline Dis charge & - & 181 & 24,614 & 23,197 & 45 & 36,108 & 23,901 \\
\hline Loss, total & 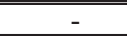 & 6,325 & $4, \mathbf{4 , 5 2 8}$ & 20,141 & 97,602 & $13, \mathbf{1 3 0 7}$ & $10 \mathbf{1 0 0 , 5 0 8}$ \\
\hline loss, charge & - & 1,081 & 2,002 & 7,458 & 16,219 & 3,422 & 21,411 \\
\hline loss, discharge & - & 36 & 1,816 & 4,822 & 9 & 2,664 & 4,968 \\
\hline loss, storing & - & 5,208 & 710 & 7,860 & 81,374 & 7,621 & 74,129 \\
\hline Charge & - & 6,506 & 29,142 & 43,338 & 97,647 & 49,815 & 124,409 \\
\hline CHP - Charge & - & 1,190 & 4,972 & 10,106 & 28,571 & 5,072 & 25,872 \\
\hline PV - Charge & - & 4,853 & 22,498 & 29,711 & 49,775 & 31,641 & 63,968 \\
\hline \multirow[t]{2}{*}{ Grid - Charge } & - & 463 & 1,672 & 3,521 & 19,300 & 13,101 & 34,568 \\
\hline & $\mathbf{w} / \mathbf{o}$ & IPV-VRLA & IPV-LFP & IPV-VRF & ILP-VRLA & ILP-LFP & ILP-VRF \\
\hline \multirow{2}{*}{$\begin{array}{l}\text { self - supply - degree } \\
\text { autarky degree }\end{array}$} & $61 \%$ & $63 \%$ & $71 \%$ & $72 \%$ & $71 \%$ & $73 \%$ & $76 \%$ \\
\hline & $75 \%$ & $74 \%$ & $81 \%$ & $78 \%$ & $58 \%$ & $83 \%$ & $63 \%$ \\
\hline
\end{tabular}

TABLE 2

SCENARIO II RESULT

\begin{tabular}{|c|c|c|c|c|c|c|c|}
\hline electricity ge ne ration $[\mathrm{kWh} / \mathrm{a}]$ & IIPV-Base & IIPV-VRLA & IIPV-LFP & IIPV-VRF & IILP-VRLA & IILP-LFP & IILP-VRF \\
\hline Total & 523,413 & 525,046 & 501,415 & 513,470 & 574,840 & 491,511 & 569,550 \\
\hline CHP - total & 174,452 & 175,630 & 179,035 & 183,610 & 196,719 & 181,052 & 202,356 \\
\hline CHP - direct use & 174,452 & 174,405 & 174,429 & 174,388 & 169,715 & 174,403 & 172,549 \\
\hline CHP - stored & - & 1,226 & 4,605 & 9,222 & 27,003 & 6,650 & 29,806 \\
\hline PV - total & 181,074 & 181,074 & 181,074 & 181,074 & 181,074 & 181,074 & 181,074 \\
\hline PV-used & 110,553 & 115,238 & 137,785 & 140,939 & 157,105 & 162,080 & 176,948 \\
\hline PV - direct use & 110,553 & 110,510 & 110,562 & 110,557 & 110,155 & 110,498 & 110,320 \\
\hline PV - stored & - & 4,728 & 27,223 & 30,382 & 46,949 & 51,583 & 66,628 \\
\hline $\mathrm{PV}$ - grid feed in & 70,522 & 65,837 & 43,290 & 40,135 & 23,970 & 18,994 & 4,127 \\
\hline Grid - total & 167,886 & 168,341 & 141,306 & 148,785 & 197,047 & 129,384 & 186,120 \\
\hline Grid - direct use & 167,886 & 167,856 & 139,109 & 143,903 & 172,960 & 104,036 & 130,462 \\
\hline Grid - stored & - & 485 & 2,196 & 4,882 & 24,087 & 25,347 & 55,658 \\
\hline electricity s tored $[\mathrm{kWh} / \mathrm{a}]$ & IIPV-Base & IIPV-VRLA & IIPV-LFP & IIPV-VRF & IILP-VRLA & IILP-LFP & IILP-VRF \\
\hline Dis charge & - & 120 & 28,790 & 24,042 & 60 & 63,954 & 39,560 \\
\hline Loss, total & - & 6,318 & 5,234 & 20,444 & 97,979 & 19,626 & 1112,532 \\
\hline loss, charge & - & 1,069 & 2,337 & 7,656 & 16,284 & 5,742 & 26,175 \\
\hline loss, discharge & - & 24 & 2,124 & 4,998 & 12 & 4,718 & 8,223 \\
\hline loss, storing & - & 5,225 & 773 & 7,790 & 81,683 & 9,166 & 78,134 \\
\hline Charge & - & 6,438 & 34,024 & 44,486 & 98,039 & 83,580 & 152,092 \\
\hline CHP - Charge & - & 1,226 & 4,605 & 9,222 & 27,003 & 6,650 & 29,806 \\
\hline PV - Charge & - & 4,728 & 27,223 & 30,382 & 46,949 & 51,583 & 66,628 \\
\hline Grid - Charge & - & 485 & 2,196 & 4,882 & 24,087 & 25,347 & 55,658 \\
\hline \multirow{2}{*}{$\begin{array}{l}\text { self - supply - degree } \\
\text { autarky degree }\end{array}$} & $54 \%$ & $55 \%$ & $63 \%$ & $63 \%$ & $62 \%$ & $70 \%$ & $67 \%$ \\
\hline & $63 \%$ & $62 \%$ & $68 \%$ & $65 \%$ & $51 \%$ & $74 \%$ & $57 \%$ \\
\hline
\end{tabular}


TABLE 3

SCENARIO III RESULT

\begin{tabular}{|c|c|c|c|c|c|c|}
\hline e le ctricity ge ne ration [kWh/a] & IIIPV-VRLA & IIIPV-LFP & IIIPV-VRF & IIILP-VRLA & IIILP-LFP & IIILP-VRF \\
\hline Total & 418,585 & 402,920 & 416,350 & 471,223 & 397,041 & 463,650 \\
\hline CHP - total & 190,301 & 187,547 & 193,583 & 230,223 & 194,644 & 228,354 \\
\hline CHP - direct use & 171,531 & 171,531 & 171,531 & 167,060 & 171,531 & 169,114 \\
\hline CHP - stored & 18,770 & 16,016 & 22,052 & 63,163 & 23,113 & 59,240 \\
\hline $\mathrm{PV}-$ total & 181,074 & 181,074 & 181,074 & 181,074 & 181,074 & 181,074 \\
\hline PV-used & 128,108 & 131,433 & 135,106 & 171,714 & 147,713 & 172,983 \\
\hline$P V$ - direct use & 103,632 & 103,632 & 103,632 & 103,632 & 103,632 & 103,632 \\
\hline PV - stored & 24,477 & 27,801 & 31,475 & 68,082 & 44,081 & 69,351 \\
\hline PV - grid feed in & 52,966 & 49,642 & 45,968 & 9,361 & 33,362 & 8,092 \\
\hline Emergency Generation - total & 47,210 & 34,299 & 41,693 & 59,925 & 21,322 & 54,222 \\
\hline Emergency Generation - direct use & 47,210 & 34,299 & 41,693 & 51,760 & 21,322 & 47,477 \\
\hline Emergency Generation - stored & - & - & - & 8,165 & - & 6,745 \\
\hline e lectricity s tored $[\mathrm{kWh} / \mathrm{a}]$ & IIIPV-VRLA & IIIPV-LFP & IIIPV-VRF & IIILP-VRLA & IIILP-LFP & IIILP-VRF \\
\hline Dis charge & 24,464 & 37,375 & 29,981 & 24,384 & $\mathbf{5 0 , 3 5 2}$ & 26,614 \\
\hline Loss, total & 18,783 & 6,442 & 23,546 & 115,026 & 16,843 & 108,722 \\
\hline loss, charge & 7,183 & 3,010 & 9,212 & 23,156 & 4,616 & 23,291 \\
\hline loss, discharge & 4,873 & 2,757 & 6,232 & 4,857 & 3,714 & 5,532 \\
\hline loss, storing & 6,727 & 675 & 8,101 & 87,013 & 8,512 & 79,898 \\
\hline Charge & 43,247 & 43,817 & $\mathbf{5 3 , 5 2 7}$ & 139,410 & 67,194 & 135,336 \\
\hline CHP - Charge & 18,770 & 16,016 & 22,052 & 63,163 & 23,113 & 59,240 \\
\hline PV - Charge & 24,477 & 27,801 & 31,475 & 68,082 & 44,081 & 69,351 \\
\hline \multirow[t]{2}{*}{ Emergency Generation - Charge } & - & - & - & 8,165 & - & 6,745 \\
\hline & IIIPV-VRLA & IIIPV-LFP & IIIPV-VRF & IIILP-VRLA & IIILP-LFP & IIILP-VRF \\
\hline self - supply - degree & $76 \%$ & $79 \%$ & $79 \%$ & $85 \%$ & $86 \%$ & $87 \%$ \\
\hline autarky degree & $82 \%$ & $88 \%$ & $82 \%$ & $64 \%$ & $90 \%$ & $66 \%$ \\
\hline
\end{tabular}

TABLE 4

NOMENCLATURE AND UNITS

\begin{tabular}{|c|c|c|c|}
\hline \multicolumn{2}{|l|}{ Nomenclature } & \multicolumn{2}{|l|}{ Units } \\
\hline Ah-model & Ampere-hours throughput model & $\mathrm{Ah}$ & Ampere hours \\
\hline $\mathrm{BDC}_{\mathrm{kWh}}$ & Battery Degradation Costs & $\mathrm{CO} 2-\mathrm{Eq}$ & Carbon Dioxide Equivalents \\
\hline $\mathrm{BEV}$ & Battery Electric Vehicle & CTUh. & Comparative Toxic Unit \\
\hline BMS & Battery Management System & $\mathrm{kWh}_{\text {inst }}$ & Kilowatt Hours Installed \\
\hline CHP & Combined Heat and Power System & $\mathrm{kWh}_{\mathrm{LT}}$ & Kilowatt \\
\hline DOD & Depth of Discharge & & Throughput \\
\hline EPEX & European Energy Exchange & $\mathrm{Sb}-\mathrm{Eq}$ & Antimony Equivalents \\
\hline ESS & Electricity Storage System & & \\
\hline ILCD & $\begin{array}{l}\text { International Reference Life Cycle } \\
\text { Data System }\end{array}$ & & \\
\hline LCA & Life Cycle Assessment & & \\
\hline LFP & $\begin{array}{l}\text { Lithium-Ion-Iron-Phosphate } \\
\text { Battery }\end{array}$ & & \\
\hline $\begin{array}{l}\text { Oemof } \\
\text { Framework }\end{array}$ & Open Energy Modelling & & \\
\hline PV & Photovoltaic System & & \\
\hline SOC & State of Charge & & \\
\hline VRF & Vanadium-Redox-Flow Battery & & \\
\hline VRLA & $\begin{array}{l}\text { Valve-Regulated-Lead-Acid } \\
\text { Battery }\end{array}$ & & \\
\hline
\end{tabular}

